\title{
Reading and Writing on Reading and Writing: Short Poetry on Flyleaves in a Manuscript of the Metrical Grammar (DCA 0oo65)
}

\author{
Anton Pritula | ORCID: 0000-0002-2354-1171 \\ State Hermitage Museum, St. Petersburg, Russia \\ HSE University, Moscow, Russia \\ pritulanna@gmail.com
}

\begin{abstract}
The short pieces discussed in the paper were added between larger texts and on the flyleaves by the scribe himself. Thematically, the poems may be divided in two blocks: the first one contains poems on reading, studying grammar, and on the scribal activities, whereas the second one comprises poetry ascribed to Bar 'Ebrōyō on different topics. The manuscript under discussion - Bar 'Ebrōyō's (1226-1286) Metrical Grammar (DCA 00065) - was written in $155^{2}$ by 'Abdīšōc of Gāzartā, an East Syrian patriarch $\left(1555^{-1570}\right)$, poet and copyist.

These small pieces forming short verse collections illustrate the complex processes that took place in the manuscript circulation and literary life during the Early Ottoman period. All the short poems were never published or studied before, and for that reason they are placed here in the Appendix in both Syriac original and English translation.
\end{abstract}

\section{Keywords}

'Abdī̌š̄' of Gāzartā - Bar 'Ebrōyō - the Metrical Grammar - Syriac poetry - short poems - flyleaves

In the present paper, some short verse pieces are discussed that were copied by 'Abdīšō' of Gāzartā, the second patriarch (1555-1570) of the Chaldean Church and an outstanding litterateur, in the manuscript DCA 00065 also written by 
him. ${ }^{1}$ The main text this manuscript contains is the Metrical Grammar by Bar 'Ebrōyō (1226-1286), ${ }^{2}$ one of the most popular works by this West Syrian Encyclopaedist. ${ }^{3}$ This copy scribed in $155^{2}$ in Mardin is unique in the sense of its circulation history, and the numerous additions made by different persons in different periods. Its peculiarities and historical significance are a subject of a special study that is to come out soon. ${ }^{4}$ As becomes clear from the manuscript colophon and the scribal notes, 'Abdīšō' of Gāzartā used the West Syriac manuscripts as a Vorlage, and was in contact with the monks from the West Syrian monasteries. ${ }^{5}$

1 Available at vHMML; permanent link: https://w3id.org/vhmml/readingRoom/view/500565.

2 See the two editions of this work: E. Bertheau (ed.), Gregorii Bar Hebraei qui et Abulpharaǵ Grammatica linquae syriacae in metro Ephraemeo, textum e cod. Bibl. Gottingensis edidit, vertit, annotatione instruxit. Göttingen: Vandenhoeck \& Ruprecht, 1843; J.-P.-P. Martin (ed.), Oeuvres grammaticales d'Abou 'lfaraj' 'dit' Bar Hebreus, Paris, 1872.

3 Over one hundred manuscripts of the work are known at present. About the extant manuscripts and editions see H. Takahashi, Barhebraeus: A Bio-Bibliography. Piscataway, NJ, 2005, pp. 358-373; On this text and the features of its copies see M. Farina, "La Grammatica Metrica di Barhebraeus (XIII sec.) e le sue glosse. Siriaco, greco e arabo in contatto", Rappresentazioni linguistiche dell'identità, ed. by M. Benedetti, Quaderni di AI $\Omega$ N, N.s. 3. Napoli, 2015, pp. 107-125.

The most recent list of the extant Mss of the Metrical Grammar see in M. Farina, "Manuscrits de grammaires et lexiques syriaques", in Les auteurs syriaques et leur langue, ed. by M. Farina, Études syriaques 15, Paris, 2018, p. 245.

A detailed study on the layout of the manuscripts of this work and the glosses found in them see M. Farina, "Barhebraeus' Metrical Grammar and Ms. BML Or. 298: Codicological and Linguistic Remarks", Studi classici e orientali 62 (2016), pp. 345-36o. Margherita Farina has also pointed out that the two-column layout (just like in both DCA 0065 and ССм 00024) was rather typical for early manuscripts of this work, having listed them (Ibid, p. 349, footnote 24). See also M. Farina, "The Syro-Arabic Glosses to Barhebraeus' Metrical Grammar", in Language and Identity in Multilingual Mediterranean Settings: Challenges for Historical Sociolinguistics. Edited by Molinelli, Piera. Trends in Linguistics. Studies and Monographs 310. Berlin / New York, 2017, pp. 157-170.

4 A. Pritula, "Abdī̌ōō of Gāzartā, Patriarch of the Chaldean Church as a Scribe", Scrinium: Journal of Patrology and Critical Hagiography, 15 (2019), pp. 297-320. On other pieces composed by him and his contemporaries and companions see J. M. Vosté, "Mar Iohannan Soulaqa, premier Patriarche des Chaldéens, martyr de l'union avec Rome ( $\uparrow 1555)$ ”, Angelicum 8, 1931, pp. 187-234; see also A. Pritula, "Abdīšóc of Gazarta, the First Literate of the Chaldean Church: Poems Dedicated to the Popes of Rome", Вестник Санкт-Петербургского университета. Востоковедение и африканистика [Vestnik of Saint Petersburg State University], vol. 10, issue 3, pp. 374-391; idem, "East Syriac Literary Life in the mid-16th Century: 'Abdīšóc of Gāzartā and Older Contemporary Poets", Вестник Санкт-Петербургского университета. Востоковедение и африканистика [Vestnik of Saint Petersburg University. Oriental and African Studies], vol. 11, issue 3, 2019: pp. 89-107.

5 Ibid. 
The poems composed by the priest Țalyā in the 18th century and added into the same manuscript are also discussed elsewhere. ${ }^{6}$ The present paper discusses just small poems, quatrains and slightly longer ones, copied by the poet and scribe himself - his hand can be easily recognized now - between larger texts and on the flyleaves. Thematically, this poetry are to be divided in two blocks, each of them being discussed here in the corresponding sections: the first one ("Block A") contains pieces on reading, studying grammar, and the scribal activities (see table 1 and the Appendix), while the second one ("Block B") comprises the ones on different topics ascribed in various manuscripts to Bar 'Ebrōyō (see table 2).

Block $B$ seems to be quite logical in a manuscript of the works by this West Syrian author, even if being a later addition to it. The origin and the nature of Block A much more difficult to characterize. Since most of these poems have been unknown to the scholars, their original text is reproduced here, as well as the English translation (see Appendix below). The layout of these pieces is reproduced as arranged in the manuscript: one or two poetic lines in a row.

\section{Block A: Poems on Reading and Scribing Books}

Most of the poems of this block were copied by 'Attāyā in CCM 00024, ${ }^{7}$ who was using 'Abdǐšo's CDA 00065 as a Vorlage for scribing a manuscript of the Metrical Grammar. ${ }^{8}$ Interestingly, the original layout of the pieces is entirely retained in his copy. It concerns also the titles of the poems in all cases they appear (for instance, see Appendix, no. 3, 6-10, 12).

Rather important is a question, whether the main text of the manuscript the Metrical Grammar caused emerging such poetic additions in the manuscripts; in other words, if their appearing there is logical or occasional. As was pointed by Margherita Farina, the glosses or the scholia to the metrical text containing linguistic explanations of the treatise were first created by the author himself, ${ }^{9}$ but later on a lot of additions by scribes and users appeared, some of them on flyleaves. ${ }^{10}$ It is also worth mentioning that in the manuscript under discussion produced by 'Abdīšō' of Gāzartā there are numerous notes on the flyleaves in both Syriac and Arabic with the linguistic explanations made in

6 A. Pritula, "From Tigris to Jerusalem: East Syriac poetic notes from the Ottoman time", Hugoyye:Journal of Syriac Studies, 22 (2019), pp. 193-234.

7 Available at vHMML; permanent link: https://w3id.org/vhmml/readingRoom/view/132226.

8 See Pritula, "Abdīšōo of Gāzartā, Patriarch of the Chaldean Church as a Scribe".

9 Farina, "Barhebraeus' Metrical Grammar", p. 35o.

$10 \quad$ Ibid, pp. $35^{\circ}-351$. 
the copyist's hand (DCA ooo65, fol. 6r-7r, 146r-148r). Thus, due to the character of the text stimulating the new commentaries of different kinds, the Metrical Grammar was accompanied by various additional texts more or less connected to it in their contents.

In their contents, the poems of this block (see Appendix) can be divided into the following groups: 1) on learning grammar (and "correctness of speech") and reading books (no. 2, 3, 4-9, 12-17) that form a majority; 2) on scribal activities (no. 1, 10, 11).

There is no doubt that the topic of studying grammar and correctness of speech (obviously implied, Syriac) was very relevant in this period. After centuries in the Muslim environment, Syriac was no longer used outside the Church. Members of Christian communities spoke and wrote in the languages of the countries in which they lived: Arabic, Turkish, Persian. This situation could not help but have an impact on the level of the churchmen's knowledge of Syriac, the main language of the book. Partly for these reasons, it seems, was the active copying of the "Metrical Grammar" of the West Syriac Encyclopedist.

Some of the poems directly praise grammar and its importance (no. $2,3,6,7$ ). In one of them, it is compared to a ship in the sea of knowledge (no. 2), and in two others - to a bridge to the knowledge (no. 6, 7). ${ }^{11}$ Thus, in all these cases its significance for the correct understanding and perception of any information contained in texts is emphasized. It is worth mentioning that the word 'grammar' is spelled in the poems in two different ways: (no. 2, 3), and بتمهيسي (no. 6, 7); both spellings of the Vorlage are retained by the copyist of CCM O0O24 in the corresponding places.

One of the quatrains (no. 1), which begins this whole block of poems and focuses on the activities of scribes, reminds us of the need to try ink and a writing stick, which the scribe must carry out before beginning to write:

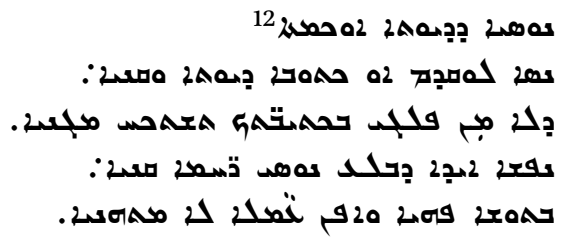

11 A ship is a rather popular trope in the Syriac literary and scribal tradition, though more often used in the colophons, comparing scribe's completion of his task to a ship reaching harbor (T. A. Carlson, "Formulaic Prose? Rhetoric and Meaning in Late Medieval Syriac Manuscript Colophons”, Hugoye: Journal of Syriac Studies, 18:2 (2015), p. 385); see also S. P. Brock, "The Scribe Reaches Harbour," Byzantinische Forschungen, 21 (1995): 198-201.

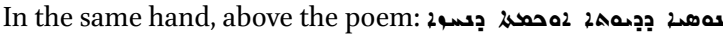

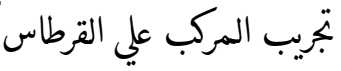




\section{Testing of the black ink ${ }^{13}$}

Oh scribe, test the ink and the reed first, so that you may not be reproached by those who doubt your writing. ${ }^{14}$ A soul that acquires friends without a trial, wanders in delusion, and even working, gains no profits. ${ }^{15}$

It is curious that in both manuscripts, where this quatrain occurs, it is located on the front flyleaf, being adjacent to test strokes, obviously representing a sample of the pen (stylus) and ink. It is likely that such a technique prefacing the text, was common in this period among the scribes of Gāzartā and nearby towns. The scribal poetic creativity, in this case apparently 'Abdī̌šc of Gāzartā, constructed a poetic text appropriate for the occasion. The quatrain has a didactic character, which is usual for works of this type, a parallel is drawn between scribe practice and the ethical problem of choosing friends.

Quatrain no. 12 is an enigma that alludes to the name of (Jesus) (see Appendix). Since it still has a connection to writing and alphabet, it can be treated as referring to the same topic, namely, studying and writing. Each line mentions a numerical value of one of the four letters of this name, which are 10, 30o, 6 and 70 correspondingly.

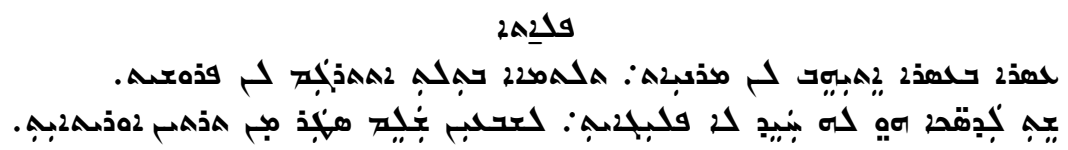

\section{Parable}

Ten is given to us lordly in the Ten.

Three hundred have wisely preached to us about the Three.

The six has connected the sides inseparably.

To the Seventy apart from the Two He delivered the Scriptures.

At the same time, in this piece, each number alludes to certain elements of events in the Holy Scripture. Thus, the first letter of the name that has the numerical value of ten, might be an allusion to the Ten Commandments. Three hundred 'preaches about the Three', i.e. about the Trinity. The six might mean the traditional elements according to the medieval natural philosophy.

\footnotetext{
13 The same rubric is given also in Arabic.

14 Or: in the middle of your writing.

15 Or: acts inappropriately.
} 
'Seventy apart from the two' may be a possible allusion to the seventy disciples of Christ that are often listed in the Syriac tradition as seventy-two.

Quatrain no. 5 discusses the use of the correct speech and praises it in various metaphors. In fact, the poet uses the method that is well-known in Arabic and Persian poetry, and called tajnis. The reader should distinguish and correctly interpret numerous homographs. Each line of the poem has its own chain of such words. This method borrowed from the neighboring Islamic poetic traditions is very suitable for such a poem that discusses the importance of the correct speech. Representing a rather uneasy reading, it requests the readers' education and good knowledge of the Syriac grammar.

Even more puzzling is quatrain no. 10, which seemingly has nothing to do the topic of reading and scribing. Instead, it looks like a description of different periods of life of a person: young age and old age. In fact, the second semantic layer is apparently connected with scribing activities (see Appendix, no. 10). The subject of the piece, as it turns out, is an ink-well. While being full, it can be easily used by a scribe, when the ink is nearly finished, it is very hard to extract and requests a special instrument. Such type of a verse text may be also characterized as a riddle or a parable. Here, polysemy of certain words is used as a poetic method. Thus, the word تمفضد that has many meanings, such as a 'funnel, metal-caster, vessel for pouring oil into a lamp' could have been used here also as a producer of ('manuscript') of the same root, i.e. a scribe, literally "pourer [of ink]", which sounds quite unusual in the new context, connected with scribal activities.

Studying this short, though extremely intriguing text-block, raises more questions that we are able to answer, both from the standpoint of methodology and history of their creation. Since the scribe obviously still owned this copy that he might have written for himself, ${ }^{16}$ he could write them not at once, but rather in different periods, about which one only may speculate. Neither is it clear whether the poems were collected by him from different places, copied from a certain Vorlage, or composed by himself, or rather these cases are somehow combined here. This problem has much more general character and concerns the numerous collections of short poems that were circulating in various types of manuscripts, often written beyond the main text scribed. First, if 'Abdišō' of Gāzartā really produced the manuscript for himself and owned it for years, there was no need for him to mention any authorship of those pieces. That definitely creates additional complexities that may be treated as a case study of autograph manuscripts.

16 See Pritula, "Abdīšōo of Gāzartā, Patriarch of the Chaldean Church as a Scribe". 
One may assume that the scribe and poet was copying and collecting any short poems that seemed to him worth doing it. Thus, five poems (nos. $5^{-10}$ ) were apparently composed by Khāmīs bar Qardahẹe (late 13th century). It is very likely, because they appear in the earliest manuscripts of his book: CCM oo419 dated 1395 (fol. 236r) ${ }^{17}$ and Vat. Sir. 186 datable to 16th century (fol. 219r). All the five pieces were also included into the printed edition of the poet's legacy that was published in Dahuk. ${ }^{18}$ Nevertheless, they were never studied or translated. Most interesting, even the order of these pieces is constant, they follow in succession, and it is also kept in 'Abdī̌šo's manuscript.

One more poem (no. 13) is ascribed Bar 'Ebrōyō at least in one early manuscript, namely Or. 298, Biblioteca Medicea Laurenziana, Florence (1487/8 AD), ${ }^{19}$ which means the piece was circulating before scribing СCM 00065. It was not included in the editions, and first published by in an article that discusses specifically the Florence manuscript. ${ }^{20}$ One more question, which we are presently unable to respond now is whether 'Abdīšō' picked Bar 'Ebrōyō's poems in the West Syriac manuscripts to which had access, ${ }^{21}$ or these texts were already circulating the East Syriac tradition.

Most likely, the scribe, who was also a famous poet, having copied already existing poems that he liked, added some of his own works on the same themes. Thus, it is possible to speak about a combination of copying poems of predecessors and creating new ones, inspired by the reading of already existing ones. Having an extremely fluid set, such text-collections might have been in a state of permanent formation and development combined with copying. This was also caused by the way and place that they circulated, namely, beyond a codification, on flyleaves as a minor addition to the main text. That is presumably how similar short-text-collections were appearing and circulating, which is in general very characteristic the medieval book transmission.

17 Available at vHMML; permanent link: https://w3id.org/vhmml/readingRoom/view/132538.

18 Š. İ. Ḥošabbā, Kāmmīs bar Qardāḥē, Mēmrē w-Mušḥâtāa . Nūhadrā [Dohuk], 2002. p. 342. The quatrains by this poet were recently studied by Alessandro Mengozzi. See A. Mengozzi, "Quatrains on Love by Khamis bar Qardahe: Syriac Sufi Poetry", Christsein in der islamischen Welt: Festschrift für Martin Tamcke zum 6o. Geburtstag. Ed. by Griffith, S. H. and Grebenstein, S. Wiesbaden, 2015, pp. 331-344.

19 See H. Takahashi, "The Poems of Barhebraeus: A Preliminary Concordance", Христианский Восток, 6 [12] (2013), p. 125.

20 M. Mazzola, "Alcuni poemi di Barhebraeus e Bar Ma'dani nella redazione del ms. Firenze, Biblioteca Medicea Laurenziana, Orientale 298", Egitto e Vicino Oriente 36 (2013), p. 83.

21 See Pritula, "Abdīšō` of Gāzartā, Patriarch of the Chaldean Church as a Scribe". 
TABLE 1 Block A: Short poems in DCA 00065 and СCM 00024 on reading and writing

\begin{tabular}{|c|c|c|c|c|}
\hline $\begin{array}{l}\text { Number } \\
\text { in the } \\
\text { block }\end{array}$ & $\begin{array}{l}\text { Folio } \\
\text { number } \\
\text { in DCA } \\
00065\end{array}$ & $\begin{array}{l}\text { Folio } \\
\text { number } \\
\text { in CCM } \\
00024\end{array}$ & Incipit & $\begin{array}{l}\text { Number of } \\
\text { lines, number of } \\
\text { syllables in a line }\end{array}$ \\
\hline 1 & fol. $3^{r}$ & & 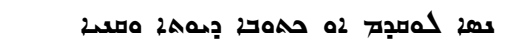 & 4 lines, 12 syllables \\
\hline 2 & fol. $3 \mathrm{v}$ & fol. $3 \mathrm{v}$ & 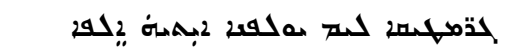 & 4 lines, 12 syllables \\
\hline 3 & fol. $3 \mathrm{v}$ & fol. $3 \mathrm{v}$ & مد دِد بذ2 لحتهابهـ & 4 lines, 7 syllables \\
\hline 4 & fol. $4 \mathrm{r}$ & - & 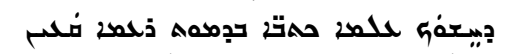 & 6 lines, 12 syllables \\
\hline 5 & fol. $5^{r}$ & fol. $3 \mathrm{v}$ & 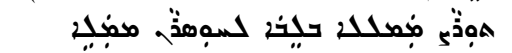 & 4 lines, 12 syllables \\
\hline 6 & fol. $5^{r}$ & fol. $3 v$ & 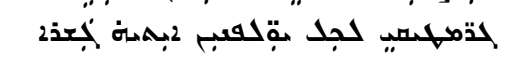 & 4 lines, 12 syllables \\
\hline 7 & fol. $5^{r}$ & fol. $3 \mathrm{v}$ & 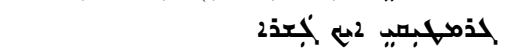 & 4 lines, 7 syllables \\
\hline 8 & fol. $5^{r}$ & fol. $3 \mathrm{v}$ & 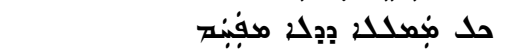 & 4 lines, 7 syllables \\
\hline 9 & fol. $5^{r}$ & fol. $3 \mathrm{v}$ & 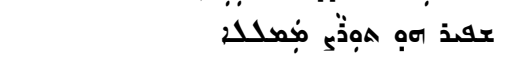 & 4 lines, 7 syllables \\
\hline 10 & fol. $5^{r}$ & fol. $4 \mathrm{r}$ & 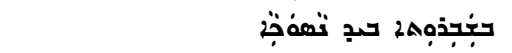 & 4 lines, 7 syllables \\
\hline 11 & fol. $5^{\mathrm{V}}$ & fol. $2 \mathrm{r}$ & 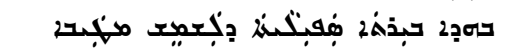 & 4 lines, 12 syllables \\
\hline 12 & fol. $5^{\mathrm{V}}$ & fol. $2 \mathrm{r}$ & 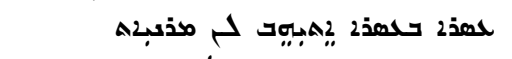 & 4 lines, 12 syllables \\
\hline 13 & fol. $5^{\mathrm{V}}$ & fol. $2 \mathrm{r}$ & 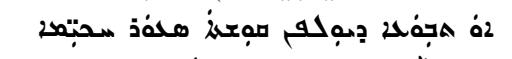 & 4 lines, 12 syllables \\
\hline 14 & fol. $5 \mathrm{~V}$ & fol. $2 \mathrm{r}$ & 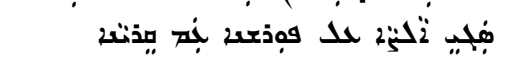 & 8 lines, 12 syllables \\
\hline 15 & fol. $114 \mathrm{~V}$ & & 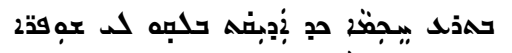 & 4 lines, 12 syllables \\
\hline 16 & fol. $141 \mathrm{r}$ & & 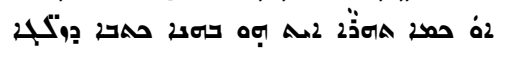 & 4 lines, 12 syllables \\
\hline 17 & fol. $142 \mathrm{r}$ & & 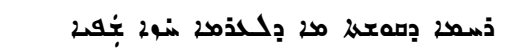 & 6 lines, 12 syllables \\
\hline
\end{tabular}

One more text-block in the same manuscript (CDA 00065 , fol. 142v-143v, $145 \mathrm{~V}$ ) - also written in 'Abdī̌̌ōs hand - is a set of poems most of which are found in various manuscripts of Bar 'Ebrōyō's poetry collection. They were not copied by 'Aț̣āāā in CCM 00024 that was using CDA 00065 as a Vorlage. ${ }^{22}$ This might mean either that he was not interested to copy them, or that they were added by 'Abdīšóc in CDA ooo65 later, after it had been used by 'Aț̣āāā. That is quite possible, since these poems are written on flyleaves. And that would also mean that the Chaldean hierarch still owned the manuscript he had written, and therefore he had scribed it for himself. All those pieces were scribed in 'Abdī̌sōss hand and have even no interval in between, being marked just by

22 See Pritula, "Abdīšō c of Gāzartā, Patriarch of the Chaldean Church as a Scribe". 
the sign of the strophic division, and the word $2 \operatorname{sim}_{2}$ (Another one) written in the same hand in red ink in the margin. Obviously, the scribe and the owner, who copied them on the flyleaves for his personal interest, was trying to spare the space.

In total, eleven poems ${ }^{23}$ out of the nineteen in this set were included into Bar 'Ebrōyō's poetry concordance by Takahashi (see table 2). ${ }^{24}$ Although not all the pieces occur in earliest manuscripts of Bar 'Ebrōyō's poetry, and included into the editions, they were obviously ascribed to him in the Syrian intellectuals of the early modernity. Anyway, they are connected together without intervals and all placed under very first rubric mentioning the ascribed author's name. Besides, they are written less cursive than the block of poems on grammar and reading. The script is very similar to the main text of the manuscript the pieces by Bar Bar 'Ebrōyō.

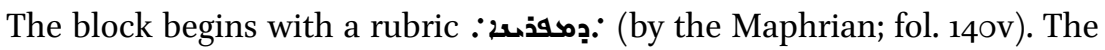
latter is clearly an epithet of Bar 'Ebrōyō, often used at least in East Syriac manuscripts, ${ }^{25}$ apparently in order to avoid a direct mention of the famous hierarch of a different confession. In CDA 00065, it is immediately followed by a series of poems with no more title that have a different number of lines (see table 2). They are included in a table below (see table 2), as belonging to the tradition reflected in the manuscripts many centuries after Bar 'Ebrōyō's death.

A poem within the block (no. 10, see table 1) has a separate rubric and is

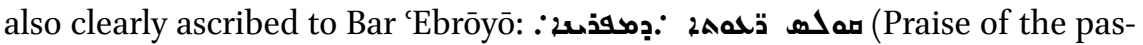
tors; by the Maphrian; fol. 142v). Nevertheless, curiously enough, this piece of twelve lines in twelve-syllable meter does not occur in the earliest manuscripts of his poetry collections, but included in the edition by Dolabani. ${ }^{26}$ Thus, in manuscript tradition, it might have been circulating under Bar 'Ebrōyō's name. It is also noteworthy that the next seven poems (Table 2, no. 11-17) that follow immediately after that one are not mentioned in the concordance by Takahashi, being absent from the earliest manuscripts and this author's poetry editions. It is possible that they are later additions to the initial poem by Bar 'Ebrōyō made by various authors (Table 2, no. 10); or even additional stanzas that were meant to complete the existing original piece, as was usual in this

\footnotetext{
23 Apart from the one mentioned above as a part of the first block (see Appendix, no. 13).

24 Takahashi, "The Poems of Barhebraeus: A Preliminary Concordance", pp. 78-139.

25 See, for instance A. Pritula, "One More Unknown Khāmīs' Ode in Honor of Bar 'Ebrōyō", Христианский Восток 8 [14] (2017), pp. 187-194.

26 See Takahashi, "The Poems of Barhebraeus: A Preliminary Concordance", pp. 138.
} 
TABLE 2 Poems in DCA 0oo65 ascribed to Bar 'Ebrōyō

\begin{tabular}{|c|c|c|c|c|}
\hline $\begin{array}{l}\text { Number } \\
\text { in the } \\
\text { block }\end{array}$ & $\begin{array}{l}\text { Folio } \\
\text { number }\end{array}$ & Incipit & $\begin{array}{l}\text { Number } \\
\text { of lines, } \\
\text { number of } \\
\text { syllables in } \\
\text { a line }\end{array}$ & $\begin{array}{l}\text { Reference to the } \\
\text { concordance of } \\
\text { the poems by Bar } \\
\text { 'Ebrōyō by Hidemi } \\
\text { Takahashi }{ }^{\text {a }}\end{array}$ \\
\hline 1 & $140 \mathrm{OV}$ & 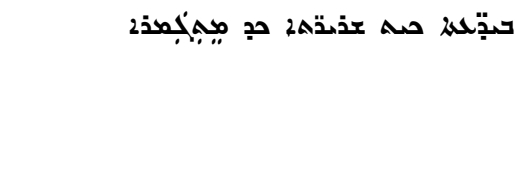 & $\begin{array}{l}4 \text { lines, } \\
12 \text { syllables }\end{array}$ & $\begin{array}{l}\text { Takahashi, p. 127; } \\
\text { Dolabani, } 7 \cdot 3 ; \\
\text { Scebabi, 111; } \\
\text { Huntington } 1,187\end{array}$ \\
\hline 2 & $140 v$ & 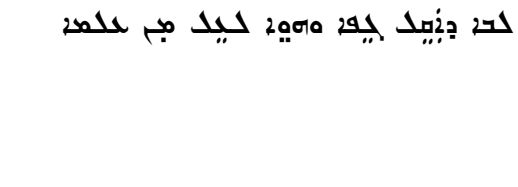 & $\begin{array}{l}4 \text { lines, } 12 \\
\text { syllables }\end{array}$ & $\begin{array}{l}\text { Takahashi, p. 133; } \\
\text { Dolabani, 10.2.2; } \\
\text { Scebabi, 246; } \\
\text { Huntington 1, } 247\end{array}$ \\
\hline 3 & $140 v$ & 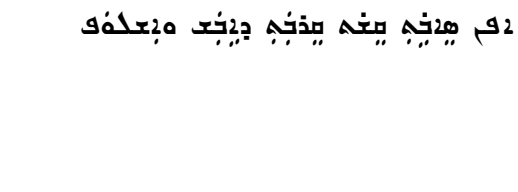 & $\begin{array}{l}4 \text { lines, } \\
12 \text { syllables }\end{array}$ & $\begin{array}{l}\text { Takahashi, p. 126; } \\
\text { Dolabani, 8.8.1; } \\
\text { Scebabi, 249; } \\
\text { Huntington 1, 250 }\end{array}$ \\
\hline 4 & $140 v$ & 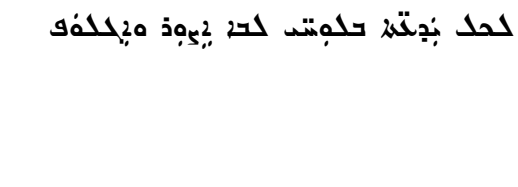 & $\begin{array}{l}4 \text { lines, } \\
12 \text { syllables }\end{array}$ & $\begin{array}{l}\text { Takahashi, p. 134; } \\
\text { Dolabani, 8.8.2; } \\
\text { Scebabi, 250; } \\
\text { Huntington 1, } 25^{1}\end{array}$ \\
\hline 5 & $140 v$ & 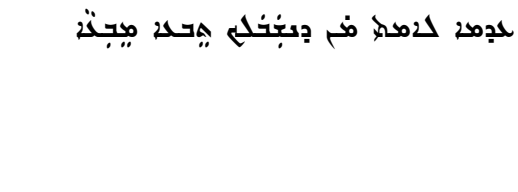 & $\begin{array}{l}4 \text { lines, } 12 \\
\text { syllables }\end{array}$ & $\begin{array}{l}\text { Takahashi, p. 137; } \\
\text { Dolabani, } 5 \cdot 15 \cdot 1 ; \\
\text { Scebabi, 254; } \\
\text { Huntington } 1,256\end{array}$ \\
\hline 6 & $141 \mathrm{r}$ & 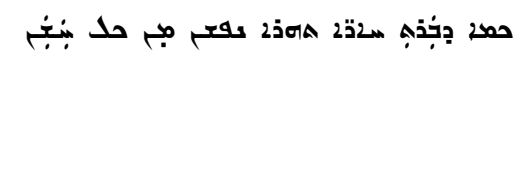 & $\begin{array}{l}4 \text { lines, } \\
12 \text { syllables }\end{array}$ & $\begin{array}{l}\text { Takahashi, p. 133; } \\
\text { Dolabani, } 5 \cdot 15 \cdot 2 ; \\
\text { Scebabi, } 255 ; \\
\text { Huntington 1, } 257\end{array}$ \\
\hline
\end{tabular}

a In this field, the reference are given following the concordance by Takahashi (Takahashi, "The Poems of Barhebraeus", pp. 78-139): number of poem in the editions by Dolabani (F. Y. Dolabani (ed.), Mušḩōtō d-Mōr Grīgōriyūs Yūḥannan Bar Ébrōōō map̄riyōnō qaddīsō d-Madnḥō, Glane / Losser, 1983) and Scebabi (A. Scebabi (ed.), Gregorii Bar-Hebraei carmina. Roma: Typographia Polyglotta, 1877); a number of poem in earliest existing manuscripts: Huntington 1 (Oxford, Bodleian Library; 1498 AD) and Laurenziana 298 (Florence, Biblioteca Medicea Laurenziana, 1487/8 AD). 


\begin{tabular}{|c|c|c|c|c|}
\hline $\begin{array}{l}\text { Number } \\
\text { in the } \\
\text { block }\end{array}$ & $\begin{array}{l}\text { Folio } \\
\text { number }\end{array}$ & Incipit & $\begin{array}{l}\text { Number } \\
\text { of lines, } \\
\text { number of } \\
\text { syllables in } \\
\text { a line }\end{array}$ & $\begin{array}{l}\text { Reference to the } \\
\text { concordance of } \\
\text { the poems by Bar } \\
\text { 'Ebrōyō by Hidemi } \\
\text { Takahashi }\end{array}$ \\
\hline 7 & $141 \mathrm{r}$ & 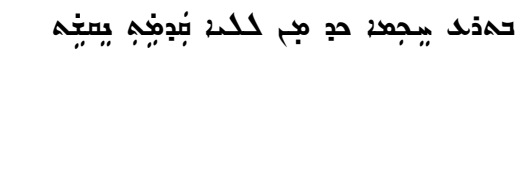 & $\begin{array}{l}4 \text { lines, } \\
12 \text { syllables }\end{array}$ & $\begin{array}{l}\text { Takahashi, p. 129; } \\
\text { Dolabani, 8.9; } \\
\text { Scebabi, 257; } \\
\text { Huntington 1, } 259\end{array}$ \\
\hline 8 & $141 \mathrm{r}$ & 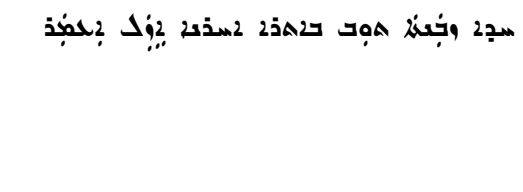 & $\begin{array}{l}4 \text { lines, } \\
12 \text { syllables }\end{array}$ & $\begin{array}{l}\text { Takahashi, p. 131; } \\
\text { Dolabani, 1.18.8; } \\
\text { Scebabi, 253; } \\
\text { Huntington 1, } 255\end{array}$ \\
\hline 9 & $141 \mathrm{r}$ & 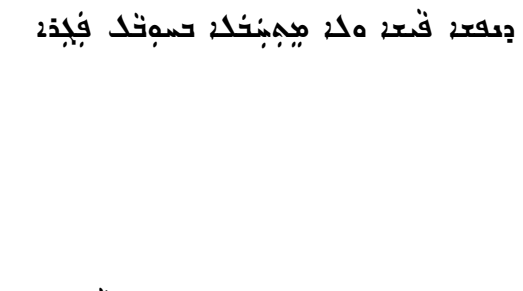 & $\begin{array}{l}4 \text { lines, } \\
12 \text { syllables }\end{array}$ & $\begin{array}{l}\text { Takahashi, p. 131; } \\
\text { Dolabani, 2.1obis; } \\
\text { Scebabi, 153; } \\
\text { Laurenziana } 298 \text {, } \\
\text { 11; Huntington 1, } \\
138\end{array}$ \\
\hline 10 & $142 \mathrm{~V}$ & 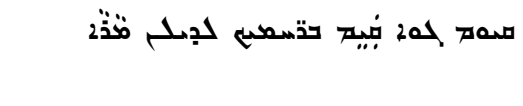 & $\begin{array}{l}12 \text { lines, } \\
12 \text { syllables }\end{array}$ & $\begin{array}{l}\text { Takahashi, p. 138; } \\
\text { Dolabani, } 3.12\end{array}$ \\
\hline 11 & $142 \mathrm{~V}$ & 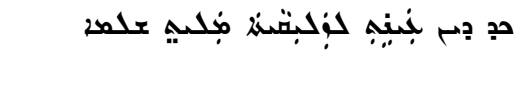 & $\begin{array}{l}8 \text { lines, } \\
12 \text { syllables }\end{array}$ & - \\
\hline 12 & $143^{r}$ & 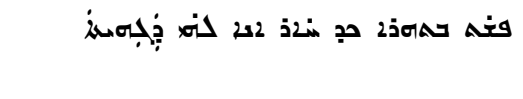 & $\begin{array}{l}10 \text { lines, } \\
12 \text { syllables }\end{array}$ & - \\
\hline 13 & $143 \mathrm{r}$ & 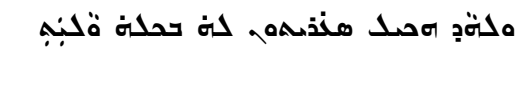 & $\begin{array}{l}8 \text { lines, } \\
12 \text { syllables }\end{array}$ & - \\
\hline 14 & $143 \mathrm{~V}$ & 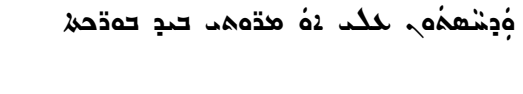 & $\begin{array}{l}4 \text { lines, } \\
12 \text { syllables }\end{array}$ & - \\
\hline 15 & & 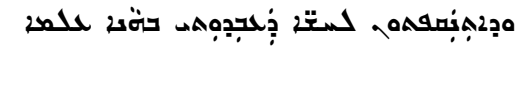 & $\begin{array}{l}4 \text { lines, } \\
12 \text { syllables }\end{array}$ & - \\
\hline 16 & $143 v$ & 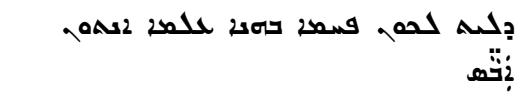 & $\begin{array}{l}4 \text { lines, } \\
12 \text { syllables }\end{array}$ & - \\
\hline
\end{tabular}


TABLE 2 Poems in DCA ooo65 ascribed to Bar 'Ebrōyō (Cont.)

\begin{tabular}{|c|c|c|c|c|}
\hline $\begin{array}{l}\text { Number } \\
\text { in the } \\
\text { block }\end{array}$ & $\begin{array}{l}\text { Folio } \\
\text { number }\end{array}$ & Incipit & $\begin{array}{l}\text { Number } \\
\text { of lines, } \\
\text { number of } \\
\text { syllables in } \\
\text { a line }\end{array}$ & $\begin{array}{l}\text { Reference to the } \\
\text { concordance of } \\
\text { the poems by Bar } \\
\text { 'Ebrōyō by Hidemi } \\
\text { Takahashi }\end{array}$ \\
\hline 17 & $\begin{array}{l}143 \mathrm{~V}- \\
144 \mathrm{r}\end{array}$ & 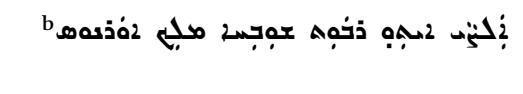 & $\begin{array}{l}12 \text { lines, } \\
12 \text { syllables }\end{array}$ & - \\
\hline 18 & $145^{V}$ & 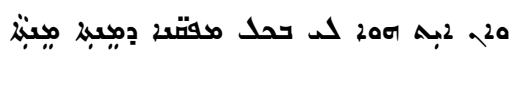 & $\begin{array}{l}8 \text { lines, } \\
12 \text { syllables }\end{array}$ & $\begin{array}{l}\text { Takahashi, p. 131; } \\
\text { Dolabani, } 3.13\end{array}$ \\
\hline 19 & $145 \mathrm{~V}$ & 2ح 2سوسهم مهمبند 2د2 حل مد بنتّ & $\begin{array}{l}6 \text { lines, } \\
12 \text { syllables }\end{array}$ & $\begin{array}{l}\text { Takahashi, p. 125; } \\
\text { Dolabani, } 1.42 .2\end{array}$ \\
\hline
\end{tabular}

b In the digital copy available at vHMML there are two more leaves between these two pieces, which might be either a later insertion or, more likely, a mistake of digitization. These folios contain later poems dated to the 18th century (see Pritula, "From Tigris to Jerusalem: East Syriac poetic notes from the Ottoman time", pp. 215-224).

period of Syriac poetry. ${ }^{27}$ It is for sure a pure speculation, since we do not have any certain information about it.

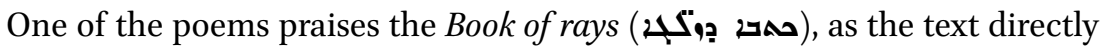
says (see no. 16). This piece seems therefore to have been initially composed by someone to accompany the mentioned theological treatise by Bar 'Ebrōyō. ${ }^{28}$ Although it is scribed on the same leaves as the block of the poems ascribed to the West Syrian author, it is placed at the very bottom in a distance from other poems of this block that are scribed without any intervals. Although copied apparently in the same hand as the former, it is scribed in a more cursive script, just like the poems on grammar and reading are. That is why I have placed it that block, assuming that it was a piece composed by 'Abdī̌šc', who drew his inspiration from reading Bar 'Ebrōyo's work. Other possibility is that the former just copied an already existing poem he liked and found suitable to include it in the set of those poems.

27 For instance, the famous poem that was Bar 'Ebrōyō that found additional stanzas by numerous authors of both West and East Syriac Churches; see Takahashi, "Barhebraeus: A Bio-Bibliography", pp. 339-341.

28 See Takahashi, "Barhebraeus: A Bio-Bibliography", pp. 65, 191-197. 


\section{Appendix}

\section{Poems on Writing and Reading: Text and Translation}

[1]

DCA 00065 , fol. 3 r

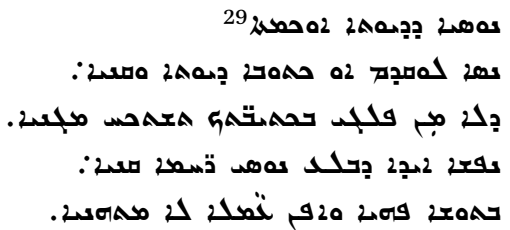

\section{Testing of the black ink ${ }^{30}$}

Oh scribe, test the ink and the reed first, so that you may not be reproached by those who doubt your writing. ${ }^{31}$ A soul that acquires friends without a trial, wanders in delusion, and even working, gains no profits. ${ }^{32}$

DCA 00065 , fol. $3 \mathrm{~V}$

CCM 00024 , fol. $3 \mathrm{v}$

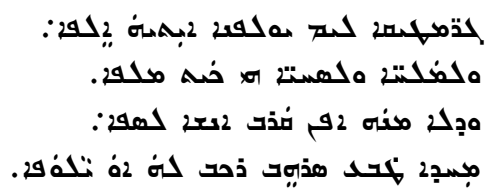

Grammar is a ship in the sea of knowledge

that instructs sailors and divers.

And since it sinks even before people reach the shore, Hurry up and drive it, oh adept!

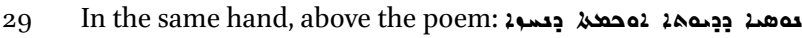

30 The same rubric is given also in Arabic.

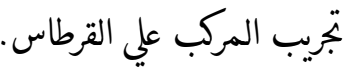

31 Or: in the middle of your writing.

32 Or: acts inappropriately. 
DCA 00065 , fol. $3 \mathrm{v}$

СCM 00024 , fol. $3 \mathrm{~V}$

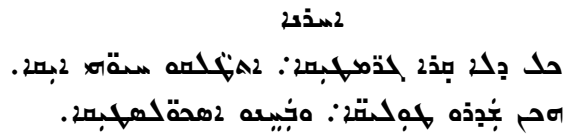

\section{Another one}

Everyone who hasn't read grammar, spent his life in vain, as the eminent have proved, and scholars have investigated.

DCA 00065 , fol. $4 \mathrm{r}$

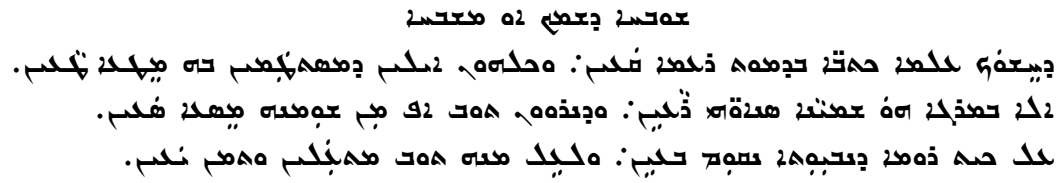

Glory to Your name, oh, the Glorious one!

Books scream about the darkness of the world like thunder.

And all who are bound to it are deceived by delusion.

But those who hate it graze on the meadow in heaven.

Those who drink from his abundance have boldness to try to reach the prophetic height, go up above it and there to increase.

DCA 00065 , fol. $5^{r}$

CCM 00024 , fol. $3 \mathrm{~V}$

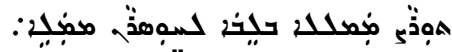

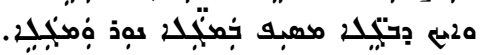

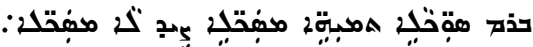

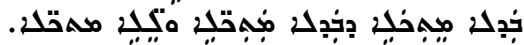


Correctness of speech replaces any shortage in the heart.

And it quenches the fire in the straw, like with the waves, and also enlightens.

Thus, it opens wonderful senses to the senseless ones, as it makes smart those who are foolish and distrustful.

DCA 00065 , fol. $5^{\mathrm{r}}$

CCM 00024, fol. $3 \mathrm{v}$

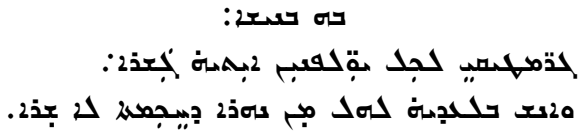

\section{On the same subject}

Grammar is a bridge to all knowledges,

and without it, one has not crossed the river of wisdom.

DCA 00065 , fol. $5^{\mathrm{r}}$

CCM 00024, fol. $3 \mathrm{v}$

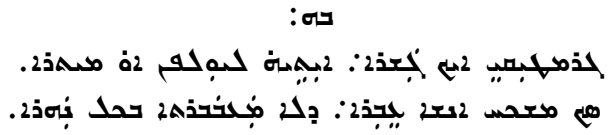

\section{On the same [subject]}

Grammar is like a bridge

to knowledge, o the virtuous one.

No one can pass [without it],

since there is no ford in the whole river.

DCA 00065 , fol. $5^{\text {r }}$

СCM 00024 , fol. $3 \mathrm{v}$

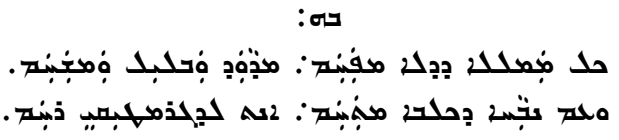


On the same [subject]

Any speech that is not balanced

is distorted, corrupt and darkened, and close to barking

[for] you, who likes grammar.

DCA 00065 , fol. $5^{\mathrm{r}}$

CCM 00024, fol. $3 \mathrm{~V}$

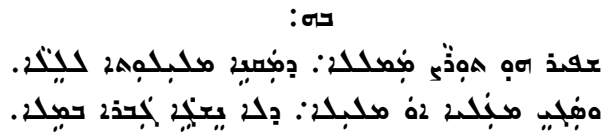

\section{On the same [subject]}

Correctness of speech is nice indeed, since it provides a foolish one with eloquence.

And it is quite sublime, oh, eloquent one, so that a man doesn't stray in speech.

DCA 00065 , fol. $5^{\mathrm{r}}$

CCM 00024, fol. $4 \mathrm{r}$

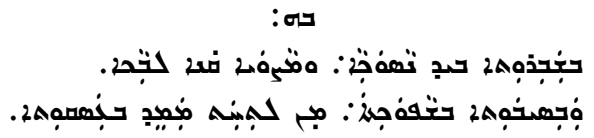

\section{By the same one}

In infancy, with a funnel

a lapper obtains his grasp.

And in old age, with a syringe

he is derived from the underneath with a difficulty.

DCA 00065 , fol. $5 \mathrm{~V}$

CCM 00O24, fol. $2 \mathrm{r}$

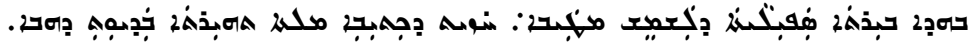

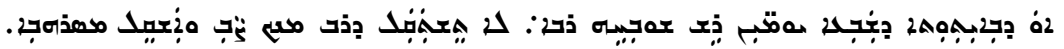


In this sapphire palace of prepared by the sun,

I saw amazing words written in golden ink.

Oh, whose glory increased with the essence of seven days,

Do not raise yourself, as [even] a larger than you appeared and departed in haste.

DCA 00065 , fol. $5 \mathrm{~V}$

CCM 00O24, fol. 2 r

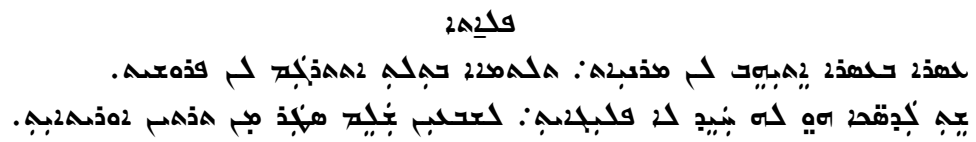

\section{Parable}

Ten is given to us lordly in the Ten.

Three hundred have wisely preached to us about the Three.

Six has connected His sides inseparably.

To the Seventy apart from the Two He delivered the Scriptures.

DCA 00065 , fol. $5 \mathrm{~V}$

CCM 00O24, fol. $2 \mathrm{r}$

Or. 298, Biblioteca Medicea Laurenziana, fol. $104 \mathrm{v}^{33}$

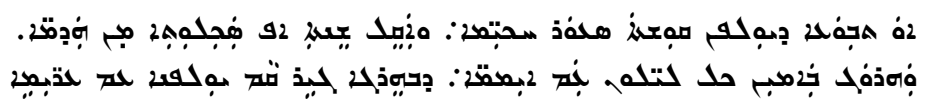

Oh, seeker of the knowledge of the Truth, act wisely.

Drive away slumber and folly from your limbs, and constantly study all days and nights,

since it is through studies that knowledge and the sage ones appeared.

33 See H. Takahashi, "The Poems of Barhebraeus: A Preliminary Concordance", Христианский Восток, 6 [12] (2013), p. 125; published in Mazzola, "Alcuni poemi di Barhebraeus e Bar Ma'dani”, pp. 73-99. 
DCA 00065 , fol. $5 \mathrm{~V}$

СCM 00024 , fol. $2 \mathrm{r}$

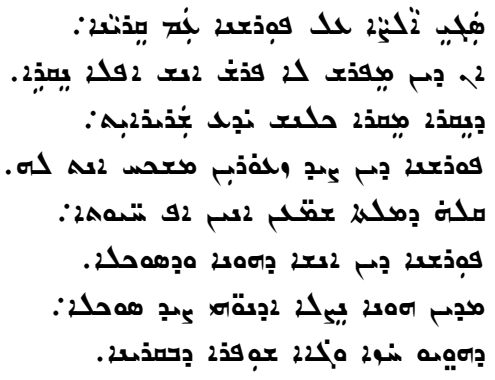

It is quite necessary for understanding and reading, that if one doesn't understand at all, not to read then.

For everyone knows how to read correctly,

but you will find understanding only among very few ones.

Even animals do hear the sound of words.

And only a man of mind and sense [has] understanding.

Therefore [his] mind inclines its ears to the sense, so that he sees and exposes the beauty of reading.

DCA 00065 , fol. 114V

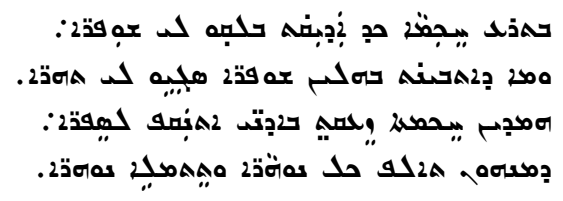

When I beheld the door of wisdom, beauties appeared to me.

And as I perceived these beauties, my amazement increased.

Thus, wisdom shouted in my ears: "Cleave unto books,

you will learn all the enlightenments ${ }^{34}$ from them and will be filled with light!"

34 Apparently, word play; both nūhrā and nuhhārā derivate of the same root and are homographs (2500). 
DCA 00065 , fol. 141r

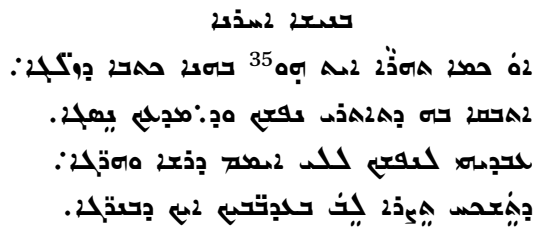

\section{On another subject}

Oh, how many wonders are gathered in this Book of Rays!

Behold how it instructs your soul and increases your knowledge.

Create studies and contemplations for your soul day and night,

So that you can split the heart of your enemies like with axes.

DCA 00065 , fol. 142r

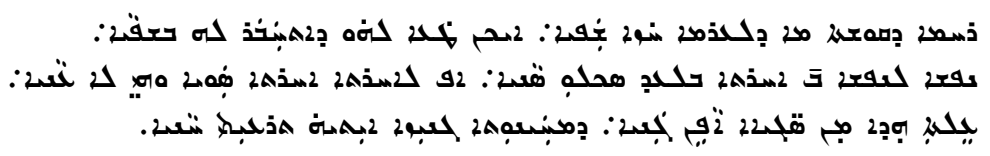

When a friend of truth sees a rugged place smooth, ${ }^{36}$

How would he deceive the one who became his sincere companion?

A soul hates a soul without any fault.

And another [soul] seeks for another one, but the latter does not respond.

Although this subject attracts many,

my mind is turned towards at the hidden vivifying. ${ }^{37}$

35 - written above the line in the same hand.

36 Apparently an allusion to an idiom: عذمد 2ك 2I will make the rugged place smooth'.

37 I.e. to spiritual subjects. 